\title{
Rebuilding public health on more than thoughts and prayers
}

\author{
J. Ross Graham ${ }^{1} \cdot$ Shannon L. Sibbald ${ }^{2}$ \\ Received: 4 February 2021 / Accepted: 13 April 2021 / Published online: 3 May 2021 \\ (C) The Canadian Public Health Association 2021
}

\begin{abstract}
Sweeping reviews will be conducted once the COVID-19 pandemic concludes to support public health system strengthening. Unfortunately, these reviews will find what past reviews on public health in Canada have found: limited evidence on the organization, financing, and delivery of public health services. This is due to inattention to the field of public health services and systems research (PHSSR) in Canada. To avoid this pandemic becoming "just another public health crisis," PHSSR must be prioritized by public health and health service research associations, funders, and scholars.
\end{abstract}

\section{Résumé}

Des révisions en profondeur seront menées à la conclusion de la COVID-19 pour appuyer le renforcement du système de santé publique. Malheureusement, ces révisions constateront les mêmes conclusions que les revues antérieures sur la santé publique au Canada : les preuves sur l'organisation, le financement et la prestation des services de santé publique sont limitées. Cela est dû au manque d'attention au domaine de la recherche sur les systèmes et les services de santé publique (RSSSP) au Canada. Afin d'éviter que cette pandémie ne devienne « rien qu'une autre crise de santé publique », la RSSSP doit être une priorité pour les associations de recherche, les donateurs et les universitaires de la santé publique et des services de santé.

Keywords Public health services and systems research $\cdot$ Public health system $\cdot$ Priority settings $\cdot$ COVID-19

Mots-clés Recherche sur les systèmes et les services de santé publique · système de santé publique · cadres prioritaires $\cdot$ COVID-19

\section{Introduction}

While the COVID-19 pandemic is a unique, seismic occurrence in many respects, it can also be viewed as the latest public health crisis in a historic pattern: (1) a public health crisis occurs (e.g., Walkerton, SARS, H1N1, COVID-19); (2) the public health system struggles to respond; (3) once the crisis ends, a sweeping review is conducted in response; (4) public health funding increases and the system structure is adjusted; and then, (5) public health funding and responsibilities are decreased (first slowly, then more significantly) until the next crisis occurs, when the cycle begins again (McLaren

J. Ross Graham

RoGraham@regionofwaterloo.ca

1 Centre for Health Services and Policy Research, University of British Columbia, Vancouver, BC, Canada

2 Faculty of Health Sciences and Schulich School of Medicine and Dentistry, Western University, London, ON, Canada
\& Dutton, 2020). While this policymaking model is common across sectors (and problematic for various reasons), this commentary takes issue with step 3: the review. Once the COVID19 pandemic is "over," our politicians will promise reforms to assure Canadians that such a crisis will not reoccur. Review committees will be struck. Well-intentioned policymakers will seize the opportunity to reform the public health system. The problem is that their review will find little evidence to guide their recommended reforms: "Unfortunately, scant evidence or analysis exists in Canada to either refute or substantiate the claimed effects of recent structural changes and funding reallocations" (Canadian Public Health Association, 2019, p. 6). Even some basic aspects of public health in Canada, such as how much it costs, optimal approaches to funding or governance, and the appropriate workforce mix, are largely unknown (Fiset-Laniel et al., 2020). A review of the landmark reports on Canadian public health systems renewal shows nearly all funding model recommendations are based on opinion, and lack an evidence basis (Graham \& Sibbald, 2017). 
The dearth of evidence on our public health system is due to the lack of attention to public health services and systems research (PHSSR): the field of study that examines the organization, financing, and delivery of public health services within communities, and the impact of these services on our health (Lenaway et al., 2006, p. 410). We echo Fiset-Laniel et al. (2020), Guyon and Perreault (2016), and others who have called for a strong PHSSR agenda for Canada. Without PHSSR evidence, we risk the COVID-19 pandemic becoming just another public health crisis, and the cycle reported above will repeat itself, with dire consequences for our health and the economy.

Many will recall that just before the COVID-19 pandemic, local and regional public health systems in most Canadian provinces were in step 5 of the cycle. Public health agencies had experienced consistent funding and scope reductions for 5 years, with no end in sight (Hancock \& McLaren, 2019). For example, in Ontario, the 34 local health departments (known as "health units") were scheduled to merge into 10 larger departments and their overall budget was to be reduced by at least 20\% (Payne, 2019) (these reforms were paused at the time of writing). All while the vast majority of Ontarians opposed such cuts (Environics Research, 2019). Similar trends were occurring in the United States, where nearly two thirds of Americans lived in jurisdictions where their local public health department had seen a budget reduction (Chen \& Dart, 2019). Proponents of these reforms, such as Ontario's current Minster of Health, reported they were needed to address the current situation where public health services were reported to be inconsistent, uncoordinated, and duplicative (Rushowy, 2019). Some also felt that increased public health attention to health promotion and health equity was evidence of "mission creep" over the past decade, and that public health should instead focus solely on health protection and infectious disease prevention activities (Spear, 2019). For example, various members of Ontario's legislature believed Ontario health units had no business investigating and addressing topics such as consumption of sugar-sweetened beverages, energy drinks, e-cigarettes, and alcohol (Rushowy, 2019; The Agenda with Steve Paikin, 2019). Sadly, we now see the clear link between inequities and various modifiable risk factors when it comes to risk of exposure to, recovery from, and/or survival of COVID19 infection (Abbasi, 2020). Turns out that infectious disease prevention, chronic disease prevention, health equity, and health protection are deeply related-who knew?

Some public health leaders responded to the planned reforms as an "erosion" to, a "threat" to, and a "weakening" of their system, concluding that public health was "under attack" (Guyon \& Perreault, 2016; Hancock, 2017; Hancock et al., 2017; Picard, 2019). Some scholars now claim these reforms hindered Canada's response to COVID-19 (Denis et al., 2020). An additional concern was that the leaders proposing these reforms seemed to have learned little from past reviews and reorganizations. For example, the central feature of most reforms was organizational change (i.e., changes to organizational charts, reporting lines, and governance structures). However, past reports, such as the Commission that examined Ontario's SARS response, suggested the value of these changes would be negligible:

Whenever a system proves wanting, it is tempting to blame its problems on structure and to embark on a course of reorganization, or centralization, or regionalization, or decentralization. It must be remembered that organizational charts do not solve problems. The underlying problems of public health in Ontario have to do with a lack of resources, years of neglect, and lack of governmental priority. These problems will not be fixed by drawing boxes on paper around public health units and moving them into other boxes (The SARS Commission, 2007, p. 225).

In our opinion, while some of the proposed public health reforms were troubling and should be reconsidered, our main concern is that without sufficient PHSSR we will never know how to better govern, structure, fund, and run an efficient and effective public health system. The COVID-19 post-mortem reviews will, once again, be based on the "thoughts and prayers" of review committee members. The cycle will repeat itself. There is a particular need for evidence on public health system governance and organization, as this seems to be the preoccupation of policymakers. Wilson-Strosher et al. (2012, p. 32) report research priorities in this area include the nature of public health leadership, impact of system restructuring, funding models, cross-jurisdiction comparisons, and interactions between public health and political systems. However, as noted by the SARS Commission, it is critical that research of the public health system organization be robust and linked with outcomes research, beyond examinations of organizational charts. Some may be surprised to read there has been limited attention to PHSSR given the abundance of public health, healthcare, and health policy scholarship across Canada. Indeed, some PHSSR does occur in Canada and there have been attempts to cultivate national and provincial attention to PHSSR (Kothari et al., 2013; Wilson-Strosher et al., 2012). However, to our knowledge, it appears dedicated attention and resourcing remain limited. Public health scholars tend to study specific public health issues and interventions, such as healthy eating, tobacco control, sexual health, and water fluoridation, rarely the system itself. Health services research scholars tend to focus on the other $\sim 95 \%$ of the health "system" that is not public health, including hospitals, physicians, nurses, drugs, and technology. Likewise, while there is significant public health-related research on the upstream determinants of health such as housing, urban planning, poverty, and childhood development, only some of this evidence translates to the public health system, which has unique context, 
services, workforce, partnerships, and approaches (Canadian Public Health Association, 2019).

The COVID-19 pandemic is an opportunity to stop the cycle of reforming public health without evidence.

With greater attention to PHSSR, we can prevent this crisis from becoming just another public health crisis. As the only segment of the health system that crosses all levels of government, there are actions we could take at all levels. For example:

- Canadian Institutes of Health Research's Institute of Population and Public Health could make PHSSR a Strategic Research Priority

- Canadian Association for Health Services and Policy Research could create a PHSSR theme group

- Canadian Journal of Public Health could dedicate issues of its journal to PHSSR

- Canadian Public Health Association could dedicate a conference to PHSSR

- Other related fields and associations, such as the Institute of Public Administration of Canada and Canadian Political Science Association, could similarly dedicate attention to the public health system

- Schools of Public Health and Faculties that educate public health practitioners (e.g., medical, nursing, nutrition, and environmental sciences schools) could prioritize faculty and student research on the public health system

While now may seem like a less than ideal time to initiate research with busy public health practitioners, we should consider the public health response to COVID-19 as a rare PHSSR natural experiment of critical importance. The system's response needs to be examined from diverse perspectives.

Now, it is important to note that even with robust PHSSR, public health leaders will still need to work to prevent politics from overriding this evidence (Hoffman et al., 2019). However, more PHSSR evidence would better equip public health leaders to educate and advocate, and it would ensure we have scholars ready to study future public health reforms, be they evidence-based or not.

\section{Code availability Not applicable}

Author contributions Both the authors contributed equally to the writing and editing, and approved of this submission.

Data availability Not applicable

\section{Declarations}

Conflict of interest The authors declare no competing interests.

Ethics approval Not applicable
Consent to participate Not applicable

Consent for publication Not applicable

\section{References}

Abbasi, J. (2020). Taking a closer look at COVID-19, health inequities, and racism. JAMA, 324(5), 427-429.

Canadian Public Health Association. (2019). Public health in the context of health system renewal in Canada. Available at: https://www.cpha. ca/public-health-context-health-system-renewal-canada.

Chen, L. W., \& Dart, B. (2019). A renewed framework for local health departments. Journal of Public Health Management and Practice, 25(1), 5-6.

Denis, J. L., Potvin, L., Rochon, J., et al. (2020). On redesigning public health in Québec: Lessons learned from the pandemic. Canadian Journal of Public Health, 111, 912-920.

Environics Research. (2019). Ontarians' attitudes towards cuts to public health units. Available at: https://www.cbc.ca/news/canada/toronto/ poll-ontarians-oppose-provincial-public-health-cuts-1.5142867.

Fiset-Laniel, J., Ak'ingabe Guyon, R. P., \& Strumpf, E. C. (2020). Public health investments: Neglect or wilful omission? Historical trends in Quebec and implications for Canada. Canadian Journal of Public Health, 111(3), 383-388.

Graham, J. R., \& Sibbald, S. L. (2017). Tinkering in the dark: Critical knowledge gaps about how to fund public health in Canada. Canadian Journal of Public Health, 108(4), e456.

Guyon, A., \& Perreault, R. (2016). Public health systems under attack in Canada: Evidence on public health system performance challenges arbitrary reform. Canadian Journal of Public Health, 107(3), e326e329.

Hancock, T. (2017). Erosion of public health capacity should be a matter of concern for all Canadians. Canadian Journal of Public Health, 108(5/6), E458-E461.

Hancock, T., \& McLaren, L. (2019). Why public health matters today. Canadian Journal of Public Health, 110(3), 259-263.

Hancock, T., Kirk, M., MacDonald, M., Neudorf, C., Sutcliffe, P., Talbot, J., \& Watson-Creed, G. (2017). The weakening of public health: A threat to population health and health care system sustainability. Canadian Journal of Public Health, 108(1), e1-e6.

Hoffman, S. J., Creatore, M. I., Klassen, A., Lay, A. M., \& Fafard, P. (2019). Building the political case for investing in public health and public health research. Canadian Journal of Public Health, 110(3), 270-274.

Kothari, A., Regan, S., Gore, D., \& Lockhart, E. (2013). Accelerating public health systems research in Ontario: Building an agenda. Western University. Available at: https:/www.uwo.ca/fhs/kt/files/ tools/think tank proceedings april 15 2013.pdf.

Lenaway, D., Halverson, P., Sotnikov, S., Tilson, H., Corso, L., \& Millington, W. (2006). Public health systems research: Setting a national agenda. American Journal of Public Health, 96(3), 410413.

McLaren, L., \& Dutton, D. J. (2020). The social determinants of pandemic impact: An opportunity to rethink what we mean by "public health spending”. Canadian Journal of Public Health, 111(4), 451-453.

Payne, E. (2019). Ontario budget's public health changes blindside officials. Ottawa Citizen. Available at: https://ottawacitizen.com/news/ local-news/ontario-budgets-public-health-changes-blindsideofficials.

Picard, A. 2019). Doug Ford's public-health cuts will come back to haunt us. Globe and Mail. Available at: https://www.theglobeandmail. com/opinion/article-doug-fords-public-health-cuts-will-come-backto-haunt-us/. 
Rushowy, R. (2019). Elliott fires back after former health ministers urge no public health cuts. Toronto Star. Available at: https://www. thestar.com/politics/provincial/2019/05/23/elliott-fires-back-afterformer-health-ministers-urge-no-public-health-cuts.html.

Spear, S. (2019). The Public Health Agency of Canada: The risk of mission creep and the need for review. MacDonald-Laurier Institute. Available at: http://macdonaldlaurier.ca/files/pdf/ 20181219_Speer_COMMENTARY_FWeb.pdf.

The Agenda with Steve Paikin. (2019). Ontario's cuts to public health. TVO. Available at: https://www.tvo.org/video/ontarios-cuts-topublic-health.
The SARS Commission. (2007). SARS and public health in Ontario: Interim report. Chapter 15: Public health restructuring (pp. 225), ON.

Wilson-Strosher, H., MacDonald, M., \& Hancock, T. (2012). Advancing public health systems and services research in Canada: Developing a pan-Canadian agenda. University of Victoria. Available at: https://www.uvic.ca/research/groups/cphfri/assets/docs/PHSSR\% 20Think\%20Tank\%20report\%20Final\%20revised.pdf.

Publisher's note Springer Nature remains neutral with regard to jurisdictional claims in published maps and institutional affiliations. 